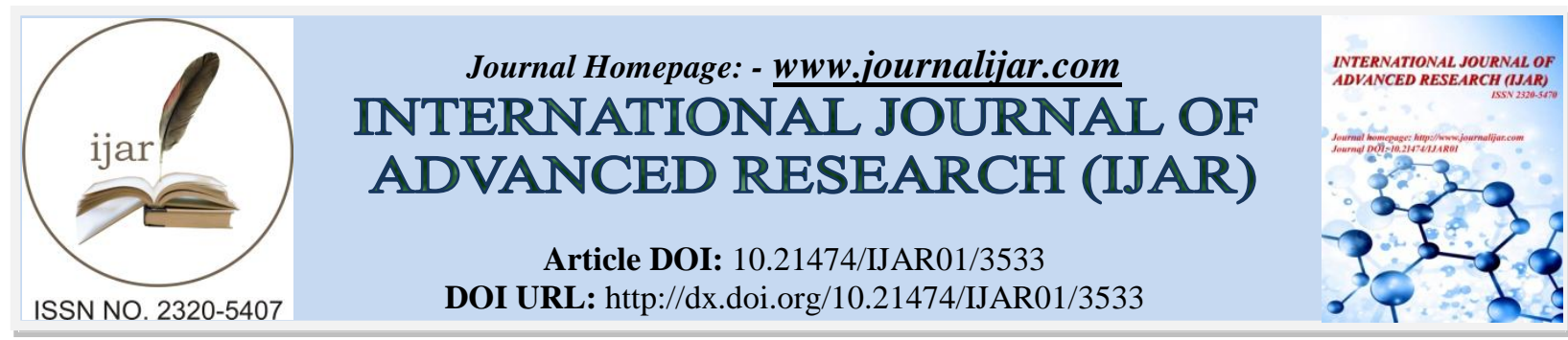

RESEARCH ARTICLE

\title{
STATISTICAL ANALYSIS OF DETERMINANTS OF CUSTOMER'S SATISFACTION ABOUT SUNDAY BAZAR AT SARGODHA, PAKISTAN.
}

\author{
Iram Sana ${ }^{1} \%$, Muhammad Iqbal ${ }^{1}$, Muhammad Tariq Jamshaid ${ }^{2}$ and Mumtaz Akhter ${ }^{3}$. \\ 1. Department of Statistics-University of Sargodha. \\ 2. Primary Secondary Healthcare Department, Lahore. \\ 3. Department of Biology, Post Graduate Degree Girls College for Women, Sargodha.
}

\section{Manuscript Info}

Manuscript History

Received: 14 January 2017

Final Accepted: 18 February 2017

Published: March 2017

\begin{abstract}
The study attempts to discover out the determinant of customer satisfaction towards Sunday bazaar in 49 Tail, PAF Road. In this study 145 responses was surveyed by useful methods. For the literature review and expert opinion it has been found that customer satisfaction are based on products, price, services, atmosphere and personal interaction. Regression Analysis was used to identify the impact of factors on customer satisfaction. The research finding out that these factors were positively impacted on customer satisfaction towards studied Sunday bazaar.
\end{abstract}

Copy Right, IJAR, 2017,. All rights reserved.

\section{Introduction:-}

In today highly competitive marketing environment the positioning decision of Sunday bazaar from store point getting goods from store point of view play important or in marketing management. Now a days shopping behavior of users has experienced a strange hanged and is putting many obstacles for market today. Sunday bazaar need to have not only the market designs to give them a better chance over the competitors but also need to develop these in a manner that uniqueness can be mainland international.

Traditionally price and differentiation of the products were consider as one of the most important factor to maintain the customers and satisfy them because Sunday bazaar owner provide their customers new varieties every Sunday. It is very important for the firms growing and development process to have customer satisfaction. Customer have become an important part of any firm especially those in the grocery retails sector and many researcher have force on the importance of the customer. Zairi (2000) cited in Singh (2006) said," customers are the purpose of what we do and rather than depending on us, we very much depend on them. The customer is not source of a problem; we should not perhaps make that customer, should go away" because our future and our security will be put in jeopardy". That is the main reason why firms today are forcing on the customers satisfaction and loyalty.

According to Hnasemark \& Albinsson (2004) cited in Singh (2006), "satisfaction is an overall attitude towards a product provider or an emotional reaction to the difference between what customers expect and what they actually receive regarding the fulfillment of a need".

We undertook survey of Sunday bazar in Sargodha and conclude that most of people shop here because it satisfied them. As the quality of product is better, not only better quality but also at reasonable price. It satisfied the customers as the get different varieties under same roof like. It saves there lot of time and also give the advantage of 
low price. Especially ladies prefer to shop here because the get advantage of getting different things like grocery, clothing, readymade food and many others.

These benefits are passed on to consumers in the form of savings. The number of the customers increase, it is more profitable for the owner of bazar as it achieve benefit of cost. As the buyers increase it also increase the quality of the different items. It promote the international market. Progress of Sunday bazar is although sow but even than customers prefer to buy the goods of daily use because it provide advantage of low price and personalized service. That is main reason why customers prefer to shop here.

\section{Literature Review:-}

Evans and Lindsay (1996) stated that companies with satisfied customers have a good opportunity to convert them into loyal customers who buy from these companies over an extended period of time. Today "in the highly competitive and dynamic business environment requires financial institutions to have satisfied customers and keep them in order to survive and compete with other players in the market successfully.

According Sivadas and Baker-Prewitt (2000), satisfaction also influences the likelihood to recommend a bank and redemption. It promotes loyalty to the extent that it is a prerequisite to maintain an attitude favorable report and recommend and bank takeover. Once customers recommend a financial institution, it promotes both redemption and loyalty to this financial institution. Thus, the key to generating loyalty is to get customers to recommend to other service provider. In addition, customers are likely to recommend a service provider when they are satisfied with the services and when they have a relatively favorable attitude to this service provider.

According Hansemark and Albinsson (2004), satisfaction is an overall attitude of clients to a service provider, or an emotional response to the difference between what customers expect and what they get, regarding the achievement of a need, purpose or desire.

Nguyen.et. al, (2007). Studied on exploring the impact of hedonic shopping motivations and attributes on a supermarket loyalty shopper. In addition, the study focuses on loyalty attitudes. loyalty behavior should be considered in future research. Founded as supermarkets attributes and hedonic shopping motivations had positive effects on shopper loyalty. And also found that the impact of hedonic motivations on shopper loyalty was different between younger and older, as well as low-income groups and higher customer. However, no difference was observed between male and female buyers.

Jayant Anand (2009). In this study evaluated the reason behind number of supermarkets in developing countries increasingly and found that large and small retailers can survive profitably by separating their markets on the basis of income groups and their product grouping.

Skallerud and Gronhaug (2010) investigated the positioning strategies supermarket Chinese food and found some important factors related to the nature of the relationship between food supply and demand for wood could be influenced by the positioning strategies of supermarkets.

Accourding to Mohsan.at.el, (2011) studied the best-performing financial institutions always seek the needs and requirements of their customers in order to survive and compete successfully in a dynamic business environment of today. That is why researchers' organization worldwide have consistently stressed the importance of customer satisfaction, loyalty and retention. The results of the study revealed that customer satisfaction is positively correlated with customer loyalty and negatively correlated with customer intentions to pass. Some recommendations for future research are also made.

Nguyễn Thị Thu Thương (2016). Studied on attempts to find out the determinants of customer satisfaction towards supermarkets in Thai Nguyen city. In this study 200 responses of the 4 selected supermarkets in Thai Nguyen city were surveyed by convenient method. The research findings showed that product, price, personal interaction, convenience, services and physical appearance were positively impacted on customer satisfaction towards studied supermarkets. Among them price had a strongest influence on customer satisfaction. 


\section{Research Methodology}

The research process consist of five main steps. The first step consist of information to relate customer satisfaction with specific reference to Sunday bazaar. The second step focuses on questionnaire based on information. The third step consist of collecting data. The forth step contains data interpretation and analysis using appropriate statistical tools. The fifth step contains an outcome of the analysis.

Likert-type scale ranging from strongly agree (1) to strongly disagree (5) was related point to each of the identified selection attributes.

Exploratory factor analysis (EFA) offers an effective way of assessing construct measures. Accordingly, item-total correlations and Cronbach's alpha were first used to assess reliability, followed by principal components analysis along with varimax rotation to explore dimensionality for each scale. In this process, the items don't meet evaluating criteria are eliminated. Criteria of refinement of item included factor loading $>0.50$, item-total correlation $>0.3$, Cronbach alpha $>0.60, \%$ of variance $>50 \%$ (Hair et al., 1998). Using SPSS 21 software we were able to assess and refine measurement scale. Regression Analysis was chosen to identify the impact of the independent variables on dependent variable (Customer Satisfaction). Primary data was collected primarily through survey method using a structured questionnaire which was designed to capture the factors impacting customer satisfaction in Sunday bazar.

\section{Sampling:-}

Samples were selected by convenience method. The interviews were conducted in person at the Sunday bazar, household, offices, schools etc. Samples were selected as students, teachers, office staff, housewives etc. Based on the number of parameters to be estimated, the sample size targeted in this study was 145 .

\section{Hypothesis:-}

In order to explore factors influenced significantly customer satisfaction and define the influenced level of these factors, sets of hypotheses were developed.

H1: There is a positive impact of product on customer satisfaction.

H2: There is a positive impact of price on customer satisfaction.

H3: There is a positive impact of personal interaction on customer satisfaction.

H4: There is a positive impact of convenience on customer satisfaction.

H5: There is a positive impact of services on customer satisfaction.

H6: There is a positive impact of physical appearance on customer satisfaction.

\section{Analysis And Discussion Of Findings:- \\ Cronbach Alpha for Scale of Factors:-}

Following the procedure and criteria described above, the Cronbach alpha results show that PR1 (Price of goods is appropriate to their quality) should be deleted due to items-total correlation of .365 under the cut-off value Cronbach alpha (0.4). The result Cronbach alpha is showed in the Table 1.

\section{EFA for all Scale of Factor Together:-}

The result of Bartlett's Test of Sphericity and KMO measure indicated that the degree of inter correlation among the items were suitable for EFA procedure $(\mathrm{KMO}=0.678>0.5$, Sig $=.000)$. After establishing the multidimensional scale and reliability of each scale, all 19 items were jointly subjected to a common factor analysis the result of this procedure shows that 6 factors consist 19 items together explained $64.667 \%$ of the total variance. In this testing, rotation method: Varimax with Principal Component Analysis was applied providing better reliability. 
Table 1:- Cronbach Alpha Reliability Test Result.

\begin{tabular}{|c|c|c|c|}
\hline Construct/items & Item & Description & $\begin{array}{l}\text { Corrected item- } \\
\text { Total correlation }\end{array}$ \\
\hline $\begin{array}{l}\text { Product-PROD } \\
(\text { Alpha }=.559)\end{array}$ & $\begin{array}{l}\text { PROD1 } \\
\text { PROD2 } \\
\text { PROD3 } \\
\text { PROD4 }\end{array}$ & $\begin{array}{l}\text { Products in Sunday bazaar is } \\
\text { durable. } \\
\text { I find product with high quality in } \\
\text { the Sunday bazaar. } \\
\text { Variety of product is good. } \\
\text { The brands sold by the Sunday } \\
\text { bazaar are good ones. }\end{array}$ & $\begin{array}{l}.558 \\
.490 \\
.651 \\
.634\end{array}$ \\
\hline $\begin{array}{l}\text { Price-PR } \\
(\text { Alpha }=.299)\end{array}$ & $\begin{array}{l}\text { PR1 } \\
\text { PR2 } \\
\text { PR3 }\end{array}$ & $\begin{array}{l}\text { Price of goods is appropriate to } \\
\text { their quality. } \\
\text { The Sunday bazaar provides special } \\
\text { discount for potential byers on } \\
\text { different occasions. } \\
\text { Prices in the Sunday bazaar are } \\
\text { competitive. }\end{array}$ & $\begin{array}{l}.365 \\
.448 \\
.783\end{array}$ \\
\hline $\begin{array}{l}\text { Personal interaction-PI } \\
(\text { Alpha=.473) }\end{array}$ & $\begin{array}{l}\text { PI1 } \\
\text { PI2 } \\
\text { PI3 } \\
\text { PI4 }\end{array}$ & $\begin{array}{l}\text { The salesmen have enough } \\
\text { knowledge to answer my question. } \\
\text { The salesmen assistance during } \\
\text { purchase is good. } \\
\text { Billing is always correct. } \\
\text { Shopkeepers are friendly and polite. }\end{array}$ & $\begin{array}{l}.761 \\
.720 \\
.687 \\
.722\end{array}$ \\
\hline $\begin{array}{l}\text { Convenience-CO } \\
(\text { Alpha }=.388)\end{array}$ & $\begin{array}{l}\mathrm{CO} 1 \\
\mathrm{CO} 2 \\
\mathrm{CO} 3\end{array}$ & $\begin{array}{l}\text { Sunday bazaar location is } \\
\text { convenient. } \\
\text { Sunday bazaar has good return } \\
\text { policies. } \\
\text { Convenient and safe parking } \\
\text { facility is available. }\end{array}$ & $\begin{array}{l}.737 \\
.714 \\
.658\end{array}$ \\
\hline $\begin{array}{l}\text { Services-SER } \\
(\text { Alpha }=.655)\end{array}$ & $\begin{array}{l}\text { SER1 } \\
\text { SER2 } \\
\text { SER3 }\end{array}$ & $\begin{array}{l}\text { Security of Sunday bazaar is very } \\
\text { good. } \\
\text { Delivery of goods is available. } \\
\text { Sunday bazaar's after sales services } \\
\text { are good. }\end{array}$ & $\begin{array}{l}.688 \\
.701 \\
.629\end{array}$ \\
\hline $\begin{array}{l}\text { Physical Appearance-PA } \\
(\text { Alpha=.275) }\end{array}$ & PA2 & $\begin{array}{l}\text { Cleanliness of the Sunday bazaar is } \\
\text { good. } \\
\text { A layout that allows me to easily } \\
\text { find the products I need. }\end{array}$ & .431 \\
\hline
\end{tabular}


Table 2:- Rotated Component Matrix ${ }^{\mathrm{a}}$

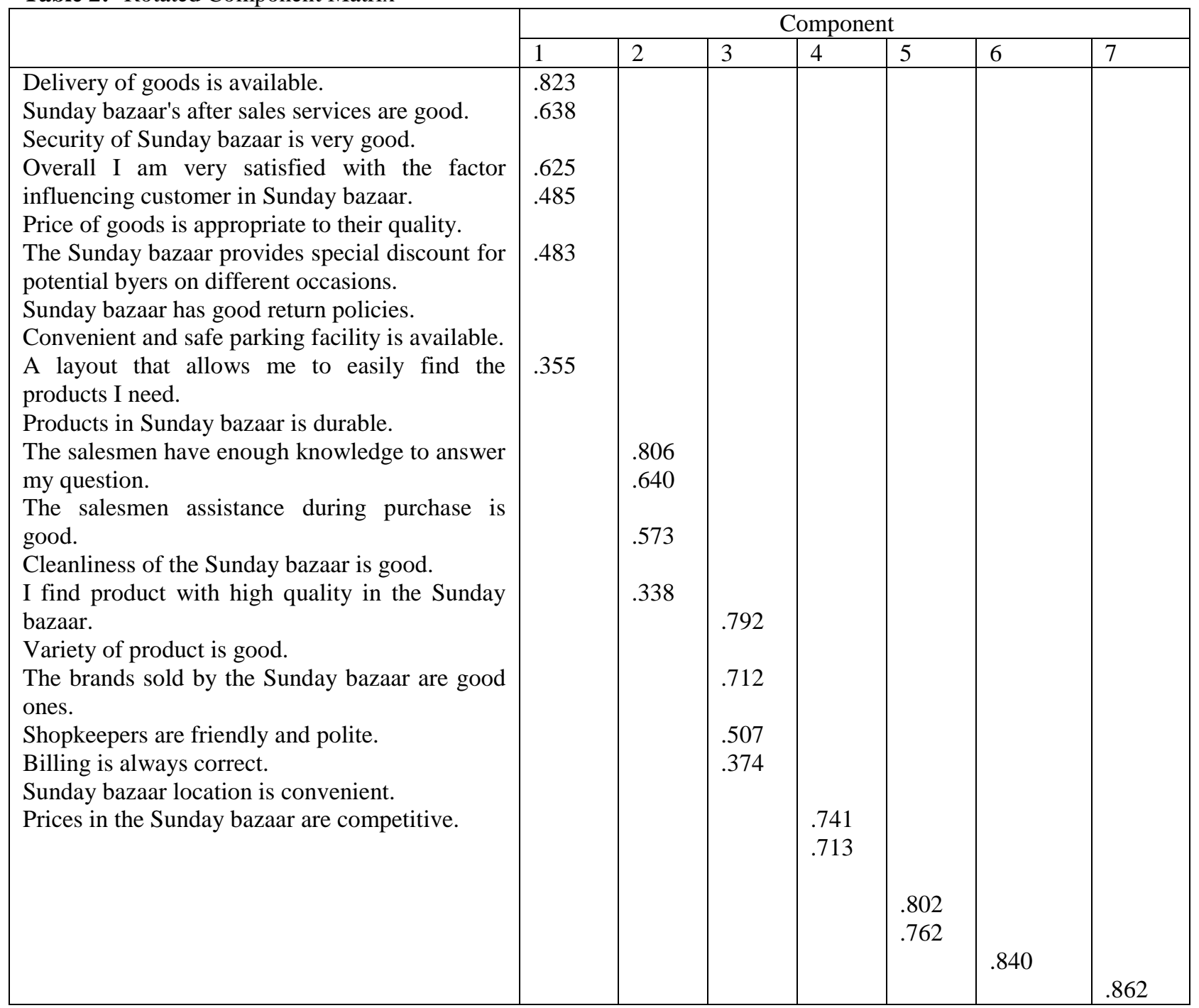

Extraction Method: Principal Component Analysis

Rotation Method: Varimax with Kaiser Normalization. ${ }^{\mathrm{a}}$

Rotation converged in 10 iteration

Testing Model and Hypotheses:-

Based on the revised model, the following function was established to present the relationship between independent variables and customer satisfaction $(\mathrm{CS})$.

$\mathrm{CS}=\mathrm{b} 0+\mathrm{b} 1 * \mathrm{PROD}+\mathrm{b} 2 * \mathrm{PR}+\mathrm{b} 3 * \mathrm{PI}+\mathrm{b} 4 * \mathrm{CO}+\mathrm{b} 5 * \mathrm{SER}$

\section{Regression Result:-}

As shown in table 3 and 4 the result indicated that $\mathrm{R}$ square $=.360, \mathrm{~F}$ value was 12.962 , sig. $=0.000$. These demonstrated that the liner multiple regressions between factors and customer satisfaction are appropriate with data and able to be used. The Sig. of factors was shown that four factors among five factors have statistical significant impact on customer satisfaction (table 5). $\mathrm{VIF}<2$, it means that there is no multicollinearity in the research model.

They are product, personal interaction, service and physical appearance with standardized coefficient range from 0.227 to 0.236 . Through the value of R square, the explanatory levels of the model is $36.0 \%$. Its mean $36.0 \%$ can be explained by the four independent varieties. 
Table 3:- Model Summaryb

\begin{tabular}{|c|c|c|c|c|c|c|c|c|c|c|}
\hline \multirow[t]{2}{*}{ Model } & \multirow[t]{2}{*}{$\mathrm{R}$} & \multirow[t]{2}{*}{ R square } & \multirow{2}{*}{$\begin{array}{l}\text { Adjusted } \\
\text { R square }\end{array}$} & \multirow{2}{*}{$\begin{array}{l}\text { Std. } \\
\text { Error of } \\
\text { Estimate }\end{array}$} & \multicolumn{5}{|c|}{ Change Statistics } & \multirow{2}{*}{$\begin{array}{l}\text { Durbin- } \\
\text { Watson }\end{array}$} \\
\hline & & & & & $\begin{array}{l}\mathrm{R} \text { square } \\
\text { Change }\end{array}$ & $\begin{array}{l}\mathrm{F} \\
\text { Change }\end{array}$ & Df1 & Df2 & $\begin{array}{l}\text { Sig. F } \\
\text { Change }\end{array}$ & \\
\hline 1 & $.600^{\mathrm{a}}$ & .360 & .333 & .372 & .360 & 12.962 & 6 & 138 & .000 & 1.468 \\
\hline
\end{tabular}

a. Predictors: (constants),PHY,PRI,PROD,PER,SER,CON

b. Dependent variable: SAT

Table 4:- ANOVA ${ }^{\mathrm{a}}$

\begin{tabular}{|cl|c|l|l|l|c|}
\hline Model & Sum of Squares & df & Mean Square & F & Sig. \\
\hline 1 & Regression & 10.753 & 6 & 1.792 & 12.962 & $.000^{\mathrm{b}}$ \\
\\
Residual & 19.081 & 138 & .138 & & \\
\\
Total & 29.834 & 144 & & & \\
\hline
\end{tabular}

a. Dependent variable: SAT

b. Predictors: (constants),PHY,PRI,PROD,PER,SER,CON

From the equations above it can be seen that one unit change in service increased by 0.236 times the level of customer satisfaction similarly one unit change in product increased by 0.227 times the level of personal loyalty.

\section{Hypothesis 1:-}

There is a positive impact of product on customer satisfaction.

The standardized regression coefficient of product on customer loyalty is $0.227(\mathrm{sig} .=0.004<0.05)$. This means that product is directly proportional to on customer satisfaction with $95 \%$ level of confidence.

Therefore, the hypothesis 1 is supported.

\section{Hypothesis 2:-}

There is a positive impact of price on customer satisfaction.

The standardized regression coefficient of price on customer loyalty is 0.084 (sig. $=0.251>0.05)$. This means at the level of confidence of $95 \%$, price do not contribute to explanation of level of customer satisfaction.

Therefore, the hypothesis 2 is rejected.

\section{Hypothesis 3:-}

There is a positive impact of personal interaction on customer satisfaction. The standardized regression coefficient of personal interaction on customer satisfaction is 0.126 ( $\mathrm{sig} .=0.089<0.05)$. This means that personal interaction is inversely proportional to customer loyalty with $95 \%$ level of confidence.

Therefore, the hypothesis 3 is rejected.

\section{Hypothesis 4:-}

There is a positive impact of convenience on customer satisfaction.

The standardized regression coefficient of convenience on customer loyalty is 0.088 (sig. $=0.290>0.05$ ). This means that convenience is inversely proportional to customer satisfaction with $95 \%$ level of confidence.

Therefore, the hypothesis 4 is rejected.

\section{Hypothesis 5:-}

There is a positive impact of services on customer satisfaction.

The standardized regression coefficient of services on customer loyalty is $0.236(\mathrm{sig} .=0.003>0.05)$. This means that services is directly proportional to customer satisfaction.

Therefore, the hypothesis 5 is supported. 
Table 5:- Coefficients ${ }^{\mathrm{a}}$

\begin{tabular}{|c|c|c|c|c|c|c|c|}
\hline \multirow[t]{2}{*}{ Model } & \multicolumn{2}{|c|}{ Unstandardized coefficients } & \multirow{2}{*}{$\begin{array}{c}\begin{array}{l}\text { Standardized } \\
\text { coefficients }\end{array} \\
\text { Beta }\end{array}$} & \multirow[t]{2}{*}{$\mathrm{t}$. } & \multirow[t]{2}{*}{ Sig. } & \multicolumn{2}{|c|}{ Collinearity Statistics } \\
\hline & $\mathrm{B}$ & $\begin{array}{l}\text { Std. } \\
\text { coefficients }\end{array}$ & & & & Tolerance & VIF \\
\hline 1 (Constant) & -.147 & .182 & & -.805 & .422 & & \\
\hline PROD & .150 & .050 & .227 & 2.967 & .004 & .790 & 1.266 \\
\hline PRI & .058 & .051 & .084 & 1.154 & .251 & .865 & 1.156 \\
\hline PER & .081 & .047 & .126 & 1.714 & .089 & .857 & 1.166 \\
\hline $\mathrm{CON}$ & .048 & .046 & .088 & 1.061 & .290 & .675 & 1.482 \\
\hline SER & .108 & .036 & .236 & 2.991 & .003 & .742 & 1.348 \\
\hline
\end{tabular}

a. Dependent variable: SAT

\section{Conclusion:-}

In Sargodha Sunday bazar is doing well and we think this types of bazars should be organized in different cities. We surveyed from different people around these areas and conclude that most of housewives, office holders and students overall they are very satisfied with the quality of product and price.

As the number of customer increase, they get more profit. The result, it is great advantage for the owners. They will provide new product and of better quality at reasonable price. This will promote international economy.

These types of bazar should be set in more cities so that every citizen can buy the different item of daily use. The manager should also focus on the negative impacts and try to improve them. Price has the highest impact on Sunday bazar, followed by product.an important conclusion from study, customers are satisfied with almost all factors.

The manager and retailers focus on the said attributes to propose appropriate promotion and positioning of Sunday bazar.

\section{References:-}

1. Evans, J. R., \& Lindsay, W. M. (1996). Management and quality control. 3rd ed, St. Paul :. West Publishing Company.

2. Hair, J. F., Anderson, R. E., Tatham, R. L., and Black, W. C. (1998) Multivariate Data Analysis. Prentice-Hall International, Inc., 5th Edition, Chapter 11.

3. Sivadass, E., \& Baker-Prewitt, J. L. (2000). An examination of the relationship between service quality, customer satisfaction and store loyalty. International Journal of Retail \& Distribution Management, 28 (2), 73 82.

4. Zairi, M 2000,"Managing Customer Dissatisfaction through Effective Complaint Management Systems", The TQM Magazine, Vol. 12(5), pp. 331-335.

5. Herman, A. and Huber, F. (2000). Value-oriented brand positioning. International Revenue of Retail, Distribution and Consumer Research, 10(1), 95-112.

6. Hansemark, O. \& C. Albinson, M., 2004, customer satisfaction and retention. The experiences of individual employees, the quality of service management, 14 (1), pp 4057

7. Singh, H 2006, "The Importance of Customer Satisfaction in relation to customer loyalty and retention", UCTI.WP-06-06, May 2006, Kuala Lumpur, Malaysia.

8. Trang T.M. Nguyen, Nigel J. Barrett, Tho D. Nguyen (2007), hedonic shopping motivations, supermarket attributes and shopper loyalty in transitional markets Proof Vietnam, Asia Pacific Journal of Marketing and Logistics, Patrington 2007. Vol.19, Issue.3

9. Jayant Anand (2009), Supermarketization, consumer choice and the changing structure of the food retail market: the case of Citlalicalli, Mexico, Dr. Donald Wood (Ed.) Economic Development, integration and morality Asia and the Americas (anthropology economics research, Volume 29), Emerald Group Publishing Limited, pp.63-88

10. Kåre Skallerud Kjell Gronhaug, (2010) "Chinese food retailers positioning strategies and influence their buying behavior", Asia Pacific Journal of Marketing and Logistics, Vol 22, Issue 2, pp.196 - 209 
11. Mohsan.F, Nawaz.M.M, Khan.M.S, Shaukat.Z, (2011). "Impact of Customer Satisfaction on Customer Loyalty and Intentions to Switch: Evidence from Banking Sector of Pakistan". "International Journal of Business and Social Science". Vol. 2 No. 16; September 2011

12. Nguyễn Thị Thu Thương (2016). "FACTORS INFLUENCING CUSTOMER SATISFACTION TOWARDS SUPERMARKETS IN THAI NGUYEN CITY, VIETNAM". "International journal of Economics, Commerce and Management". Vol. IV, Issue 2, February 2016 